\title{
PENGEMBANGAN INDUSTRI KREATIF SIRUP JAMU SEHAT UNTUK PEMBERDAYAAN POSDAYA DI KABUPATEN SIDOARJO
}

\section{DEVELOPMENT OF INDONESIAN HERBAL MEDICINE (JAMU)-BASED CREATIVE INDUSTRY FOR EMPOWERING POSDAYA IN SIDOARJO}

\author{
Djoko Agus Purwanto \\ Departemen Kimia Farmasi, Fakultas Farmasi, Universitas Airlangga, Kampus B, Jl. \\ Dharmawangsa Dalam, Surabaya, 60286, Indonesia. Tel/fax: +62-31-5030-710/+62-31-5020- \\ 514, E-mail: djokoagus@yahoo.com \\ Achmad Toto Poernomo \\ Departemen Kimia Farmasi, Fakultas Farmasi, Universitas Airlangga, Kampus B, Jl. \\ Dharmawangsa Dalam, Surabaya, 60286, Indonesia. Tel/fax: +62-31-5030-710/+62-31-5020- \\ 514, E-mail: achmad.toto.p@gmail.com \\ Febri Annuryanti \\ Departemen Kimia Farmasi, Fakultas Farmasi, Universitas Airlangga, Kampus B, Jl. \\ Dharmawangsa Dalam, Surabaya, 60286, Indonesia. Tel/fax: +62-31-5030-710/+62-31-5020. \\ 514, E-mail: febri-a@ff.unair.ac.id
}

\begin{abstract}
Indonesian people should be proud of its great natural biodiversity with precious ancestral heritages, such as Indonesian traditional medicine or Jamu. It has been intended to diversify the product of jamu that are affordable and healthy. Recently, it has been known that some luxury hotels in Indonesia creates jamu as a welcome drink, which is not only fresh but also healthful, to attract foreign customers. Empowering the community to be able making jamu syrups is importantly required for attracting many tourists to visit Indonesia. In this program, about 10 and 11 residents in the neighbourhood (RT) of 25 and 59, respectively, in Kebon Agung village, Sukodono district, Sidoarjo Regency were involved. They were trained for making jamu syrup made from lemongrass and mangosteen's peel using health manufacturing process of traditional medicine i.e., without any chemical preserving, coloring, and taste masking agents, as well as hygienic packaging methods that can be long lasting, aesthetic appearing, and worth selling. The program consisted of training, mentoring, and lecturing to explain the making process of lemongrass and mangosteen peel syrups. The program was conducted until all participants were able to produce their own products well. The first production target was about each 200 bottles of lemongrass and mangosteen peel syrup could be sold. Bottle packaging, packaging equipment, and other supporting equipment will be delivered entirely as initial capital of POSDAYA. Hopefully, after the program is completed, the sustainability of this effort can be continued under the guidance of Universitas Airlangga.

Keywords: jamu, lemongrass, mangosteen's peel, POSDAYA, syrup
\end{abstract}

\section{Abstrak}


Bangsa Indonesia patut berbangga memiliki keanekaragaman hayati yang luar biasa ditambah dengan warisan nenek moyang yang berharga, salah satunya adalah jamu Saat ini, dirasakan perlu dilakukan diversifikasi pengembangan jamu sebagai minuman sehat sehingga tercipta jamu yang murah, terjangkau masyarakat, dan sehat. Ada kecenderungan beberapa hotel berbintang di Indonesia menciptakan jamu sebagai welcome drink untuk menarik pelanggan, yang tidak hanya segar tetapi juga menyehatkan. Pemberdayaan masyarakat untuk bisa membuat sirup minuman jamu yang sehat perlu lebih dikembangkan sehingga diharapkan dapat menarik wisatawan yang ingin berkunjung ke Indonesia. Dalam kegiatan ini telah dapat dilatih 10 orang warga RT 25 dan 11 orang warga RT 59 Desa Kebon Agung, Kecamatan Sukodono, Kabupaten Sidoarjo dalam pembuatan sirup sereh dan sirup kulit buah manggis dengan cara yang sehat, yaitu tanpa pengawet, tanpa pewarna, dan tanpa penambah rasa, sekaligus cara pengemasannya yang higienis sehingga dapat bertahan lama, memenuhi persyaratan estetis, dan layak jual. Metode yang digunakan adalah pelatihan, pendampingan, serta ceramah untuk menjelaskan pembuatan sirup sereh dan sirup kulit buah manggis hingga peserta mampu memproduksi sendiri dengan baik dan benar. Produksi pertama ditargetkan dapat dibuat 200 botol sirup sereh dan 200 botol sirup kulit buah manggis yang layak untuk dijual. Pembelian botol, peralatan pengemasan botol, dan alat-alat pendukung lainnya akan diserahkan seluruhnya sebagai modal awal dari POSDAYA. Harapannya setelah program selesai, keberlanjutan usaha ini dapat terus dilakukan di bawah binaan Universitas Airlangga.

Kata kunci: jamu, kulit buah manggis, POSDAYA, sirup, sereh

\section{PENDAHULUAN}

Bangsa Indonesia patut berbangga memiliki keanekaragaman hayati yang luar biasa ditambah dengan warisan nenek moyang berupa jamu yang patut kita hargai dan kita kembangkan bersama (Santoso 1995). Telah banyak dikembangkan sediaan jamu mulai dari serbuk tanaman, ekstrak, kapsul, tablet effervescent dan sebagainya sehingga sediaan jamu terus berkembang mengikuti perkembangan jaman (Saerang 2009). Di kalangan generasi muda, kadangkala jamu masih dianggap kuno dan kurang berkhasiat. Akan tetapi sebelum bangsa Indonesia mengenal obat modern, penggunaan jamu telah di lakukan selama ratusan tahun dan jamu merupakan obat satu-satunya yang dapat diandalkan pada masa lalu. Oleh karena itu pengembangan industri jamu sebagai minuman sehat perlu dilakukan diversifikasi sehingga keberadaan jamu yang murah, terjangkau masyarakat dan sehat tetap dibutuhkan di jaman modern ini.

Seperti di Indonesia, di Jepang sudah menjadi budaya jika tamu yang datang kerumah kita selalu ada suguhan baik makanan maupun minuman. Akan tetapi di Jepang, makanan atau minuman yang disuguhkan merupakan makanan sehat, misalnya es krim teh hijau, kue anti kolesterol, jus untuk tekanan darah tinggi, kue anti diabetes, anti kanker dan sebagainya. Kondisi ini sangat baik untuk 
disosialisasikan sehingga bangsa ini menjadi bangsa yang sehat. Beberapa hotel berbintang di Indonesia telah melihat peluang untuk menarik pelanggan dengan memberikan welcome drink yang tidak hanya segar tetapi juga menyehatkan (Siesta 2014). Hal ini memunculkan pangsa pasar yang besar untuk menggalakkan minuman kesehatan di masyarakat. Manfaatnya tidak hanya ditinjau dari sisi finansial saja, tetapi melestarikan budaya Indonesia dan menyehatkan bangsa. Oleh karena itu, pemberdayaan masyarakat untuk bisa membuat sirup minuman jamu yang sehat perlu di tumbuh kembangkan di Indonesia sehingga diharapkan dapat menarik wisatawan yang ingin berkunjung ke Indonesia.

Di Desa Kebon Agung Kabupaten Sidoarjo, sebagai mitra kegiatan, terdapat 2 Rukun Tetangga (RT), yaitu RT 25 dan RT 59 yang merupakan 2 RT yang saling berhadap-hadapan dan dipisahkan oleh jalan selebar 6 meter. Daerah Kebon Agung ini banyak dijumpai pohon manggis dan juga sereh, namun pemanfaatannya kurang maksimal. Kalau kedua jenis obat tradisional ini dapat dijadikan minuman instan berupa sirup sehat, maka besar harapan dapat laku di pasar sehingga meningkatkan pendapatan masyarakat daerah Kebon Agung. Di samping hal tersebut, pengembangan usaha ini akan memicu daerah sekitar untuk memanfaatkan tumbuhan berkhasiat obat untuk dijadikan sirup sehat.

Sirup kulit buah manggis memiliki banyak khasiat diantaranya adalah anti kanker, melindungi terhadap serangan stroke dan penyakit jantung koroner sehingga mengkonsumsinya setiap hari sangat baik. Kandungan senyawa aktif, yaitu xanthone yang merupakan golongan polifenol bersifat free radical scavenger, dan anti oksidan sehingga baik untuk mencegah dan mengobati penyakit-penyakit degeneratif.

Penggunaan sirup sereh tidak kalah pentingnya Karena aromanya sangat berkhasiat untuk mengurangi rasa stres, sulit tidur (insomnia), menurunkan tekanan darah tinggi dan meringankan rasa pegal-pegal. Sirup sereh dapat membuat badan terasa lebih segar, lebih rileks, dan rasa tenang. Sereh mengandung minyak atsiri yang berfungsi menghangatkan badan. Rasanya yang enak dan hangat menyebabkan banyak orang yang menyukainya.

Terdapat beberapa permasalahan yang dihadapi oleh mitra di desa Kebon Agung saat ini, antara lain tanaman sereh dan manggis yang berlimpah, namun pemanfaatannya masih kurang maksimal karena hanya dijual sebagai bumbu dapur dan buah, serta kulit buah manggis juga hanya dibuang ke bak sampah. Selain itu, kegiatan warga khususnya ibu-ibu tidak ada. Posyandu ataupun Pos 
Pemberdayan Keluarga (POSDAYA) tidak ada, yang ada hanyalah perkumpulan arisan. Di kedua RT tersebut, yaitu RT 25 dan RT 59, terdapat dikarenakan penghuni RT 25 yang merupakan penduduk asli, sedangkan warga RT 59 mayoritas merupakan pendatang. Dengan adanya kegiatan bersama ini, diharapkan akan terjalin kebersamaan antara kedua RT, disamping juga menjadi kegiatan yang bermanfaat. Namun, kegiatan tersebut harus dapat dikerjakan di dalam rumah sebagai mata pencaharian tambahan serta diperlukan ketrampilan dan pengetahuan khusus agar produk yang dihasilkan aman, bermanfaat, dapat dipasarkan, dan mendatangkan pendapatan dalam waktu yang tidak terlalu lama.

Mengingat kondisi sosial-ekonomi warga desa Kebon Agung tersebut, maka dibutuhkan pengembangan industri kreatif yang berbasis pengetahuan obat tradisional yang saat ini mulai dibutuhkan oleh masyarakat seperti untuk keperluan rumah tangga, restoran, hotel, catering dan sebagainya. Sebagai upaya untuk mengatasi hal tersebut, maka dilakukan pembentukan POSDAYA, dimana POSDAYA tersebut harus memiliki anggaran dasar/anggaran rumah tangga (AD/ART) dan Program Kerja. Oleh karena itu, terdapat program pelatihan untuk penyusunan AD/ART dan program kerja dengan arahan dan pendampingan yang akan diberikan oleh dari Tim Universitas Airlangga.

Dalam kegiatan in, dilakukan pelatihan pembuatan sirup jamu sehat kepada 10 orang warga RT 25 dan 10 orang warga RT 59 desa Kebon Agung, Kec. Sukodono, Sidoarjo, Jawa Timur. Teknologi pembuatan jamu harus memenuhi syarat kesehatan, tidak mengandung bahan-bahan berbahaya, dan tetap menjamin khasiat sereh dna manggis, diantaranya meliputi tehnik melakukan ekstraksi, pemanasan, pengawetan, bahan tambahan apa yang diperbolehkan dan berapa kadarnya, serta bagaimana teknis pencampuran hingga aspek sterilisasi sediaan. Pelatihan pembukuan keuangan, manajemen produksi, dan pemasaran juga dilakukan. Pembukuan keuangan yang akuntabel mutlak harus diterapkan untuk menjaga keberlangsungan usaha karena kegiatan ini bukan milik perorangan, tetapi kelompok.

Tim Lembaga Penelitian dan Pengabdian kepada Masyarakat (LPPM) Universitas Airlangga telah memiliki pengalaman untuk pelatihan pembuatan sirup jamu yang sampai sekarang terus diajarkan baik pertemuan POSDAYA, daerah binaan, maupun pada desa lain yang membutuhkan. Dengan demikian, diharapkan pelatihan pembuatan sirup jamu ini dapat disebarkan ke daerah lain sehingga banyak daerah dengan kearifan local di Indonesia dapat menghasilkan 
produk yang serupa. Hal ini guna merangsang tumbuhnya sentra- sentra jamu dengan berbagai sediaan sehingga dapat menghidupkan usaha rakyat.

\section{METODE PELAKSANAAN}

Pelaksanaan kegiatan dilakukan dengan tahapan sebagai berikut: Pembentukan POSDAYA.

Tahap pertama dari kegiatan ini adalah pembentukan POSDAYA sebagai penguatan kelembagaan untuk melakukan suatu usaha. POSDAYA merupakan wadah organisasi yang dapat dimanfaatkan bersama oleh masyarakat yang salah satunya untuk membangun dan mengembangkan kewirausahaan. Seperti diketahui, ada 4 pilar program POSDAYA yaitu pendidikan, kesehatan, lingkungan, dan pemberdayaan masyarakat. Dengan adanya POSDAYA ini diharapkan nantinya dapat dikembangkan kegiatan yang positif yang menunjang keberlanjutan program.

Identifikasi peluang usaha.

Pengembanganm kewirausahaan merupakan salah satu solusi untuk meningkatkan kesejahteraan masyarakat. Potensi daerah perlu diidentifikasi dengan cermat di samping melihat peluang usaha yang ada agar kegiatan usaha yang produktif dapat dikembangkan yang pada akhirnya dapat menambah penghasilan masyarakat. Penggunaan minuman jamu tidak hanya diminati oleh kalangan bawah, namun juga kalangan atas, para wisatawan dan tamu hotel berbintang dikarenakan jamu dikenal menyehatkan. Dari hasil studi yang telah dilakukan, para tamu hotel lebih memilih jamu daripada minuman lain. Hal ini menunjukkan peluang usaha minuman sirup jamu masih disukai hingga saat ini.

Solusi atas permasalahan.

Disamping meningkatkan penghasilan masyarakat, kegiatan produksi minuman jamu juga dapat menurunkan gap dan kesenjangan social sehingga dapat mencegah terjadinya konflik. Persoalan yang seharusnya dapat diselesaikan secara mudah akan menjadi rumit dengan adanya gap. Pada pertemuan awal dapat diidentifikasi bahwa 2 RT yang berdekatan ini menunjukkan keinginannya untuk bekerja bersama dan membangun kegiatan yang positif sehingga kegiatan ini juga menjadi sarana untuk meningkatkan kerukunan. Bahkan telah dirancang untuk membangun kampong Tanaman Obat Keluarga (TOGA) yang asri dan sehat baik jasmani maupun rohani. 
Pelatihan dan pengembangan produk.

Pelatihan pengembangan produk kewirausahaan sirup jamu akan dilakukan oleh pengusul beserta staf dosen Fakultas Farmasi lainnya karena tidak mungkin mencantumkan semua nama dalam proposal ini. Selain hal tersebut, dilibatkan sekitar 10 orang mahasiswa yang tidak hanya sekedar membantu jalannya pengabdian kepada masyarakat ini, tetapi juga memberikan kesadaran bagi mahasiswa akan perlunya menerapkan ilmunya untuk meningkatkan kesejahteraan masyarakat.

Manajemen produksi dan pemasaran.

Manajemen produksi dan pemasaran akan diberikan dalam bentuk ceramah dan pendampingan oleh staf dari fakultas ekonomi dengan menyiapkan beberapa dokumen pembukuan serta membekali peserta tentang teknik-teknik pemasaran yang efektif sehingga kegiatan usaha dapat berlangsung terus-menerus. Dengan adanya laporan keuangan yang baik akan menghindari saling curiga dan ketidak puasan dalam melakukan usaha.

Keberlanjutan kegiatan.

Penguatan kelembagaan dan sistem produksi maupun keuangan yang baik akan membantu kegiatan usaha akan berlangsung dengan baik. Transparansi, kejujuran, dan pembukuan keuangan yang dapat diterima semua anggota akan menghindarkan dari perpecahan dan berhentinya kegiatan. Hal ini merupakan aspek yang tidak kalah pentingnya dibanding aspek teknologi yang di aplikasikan.

\section{HASIL DAN PEMBAHASAN}

Pada tahap persiapan, peserta dari RT 25 dan RT 59 diundang untuk melakukan koordinasi terhadap kegiatan pengabdian masyarakat tentang pembuatan sirup jamu di Desa kebon Agung, Kecamatan Sukodono, Sidoarjo. Pada tahap ini, ibu-ibu anggota dan pengurus PKK tingkat desa juga hadir. Pada tahap persiapan, telah terbentuk POSDAYA SRIKANDI yang diketuai oleh Ibu Fauzi Wibowo.

Selanjutnya adalah tahap pelatihan. Pada tahap ini, peserta dilatih secara praktis untuk membuat sirup jamu dari kulit manggis tanpa menggunakan pengawet, pewarna maupun zat kimia lainnya sehingga bisa dijamin menjadi minuman yang menyehatkan. Untuk zat warna dan perasa ditambahkan ekstrak bunga rosela yang berwarna merah dan rasanya yang masam segar sehingga sirup 
terlihat berwarna merah. Peserta dibagi dalam 2 group dan masing-masing mencoba sendiri pembuatan sirup jamu dengan dilakukan pengawasan oleh instruktur (Gambar 1A). Hasilnya diuji rasa dan kelayakan, serta dibuat dalam bentuk kemasan dan dibeli label yang menarik sehingga diharapkan layak untuk dijual (Gambar 1B).
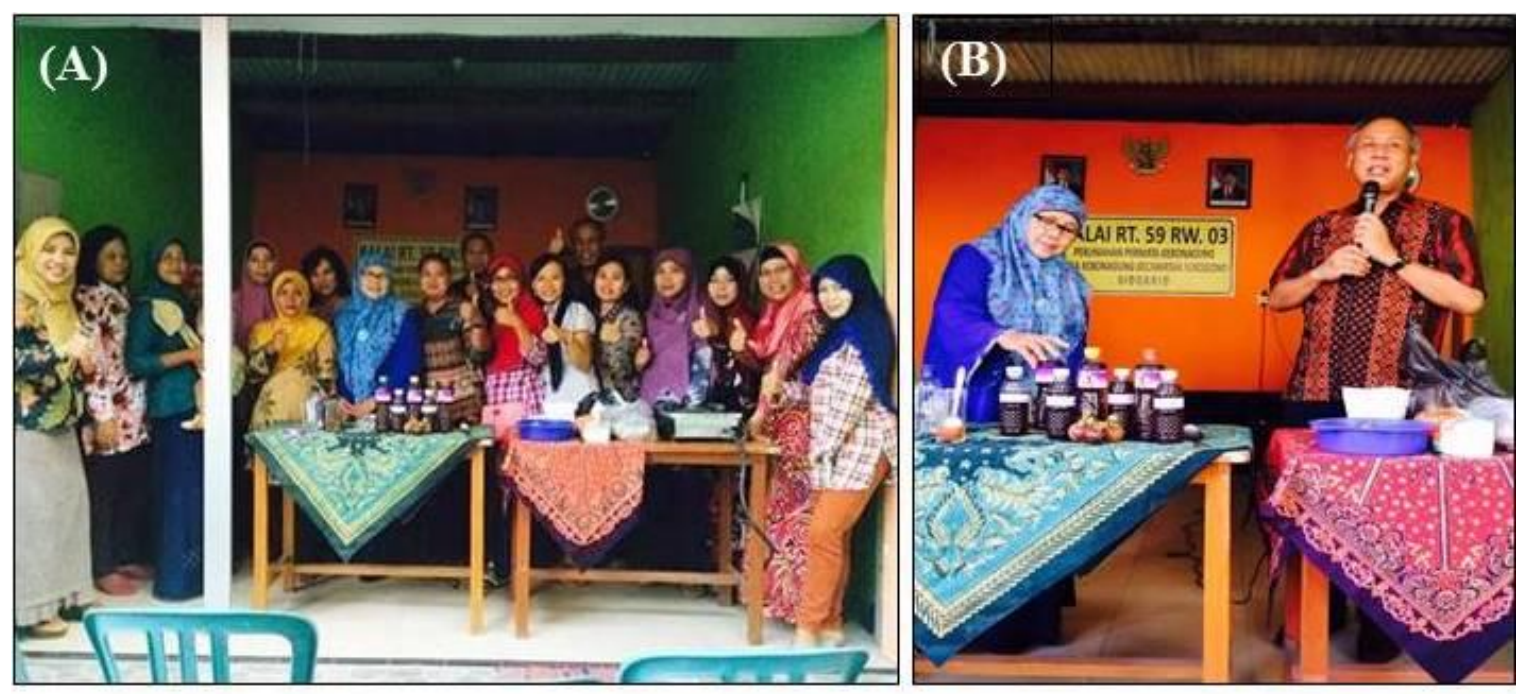

Gambar 1. Pemberian pelatihan dalam pembuatan sirup kulit buah manggis pada warga RT 25 dan RT 59, desa Kebon Agung, Kecamatan Sukodono, Sidoarjo (A). Produk sirup kulit buah manggis yang dibuat secara sehat, tanpa pengawet, tanpa zat warna, tanpa penambah rasa (B).

Selanjutnya adalah tahap produksi. Tahap ini dilakukan setelah peserta mendapatkan komposisi resep sirup yang paling optimal, baik rasa maupun warna sehingga produksinya dapat dijual ke masyarakat. Selain membuat sirup (Gambar 2), para peserta bersepakat untuk membuat minuman langsung jadi yang akan menggunakan sirup yang sudah diajarkan. Harapannya agar pengetahuan dan teknologi yang diberikan dapat bermanfaat bagi masyarakat untuk mengembangkan produk sirup jamu yang sehat. Resep sirup jamu sehat yang telah dihasilkan adalah tanpa pengawet, tanpa pewarna, dan tanpa pemanis buatan, baik itu sirup kulit manggis maupun sirup sereh-secang (Gambar 2). 


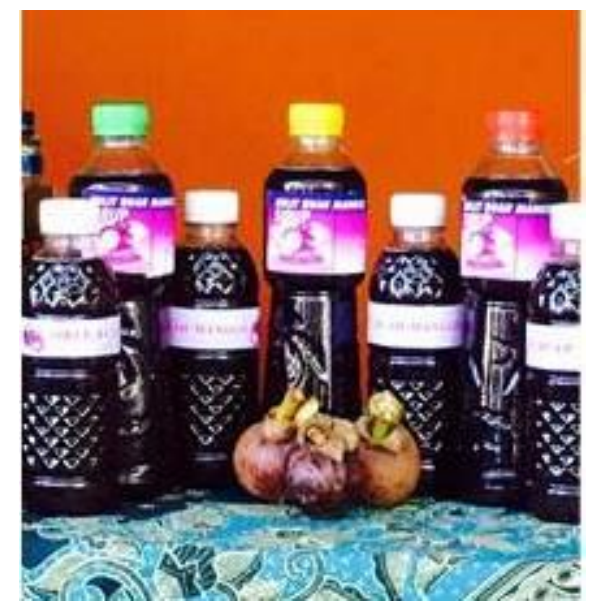

Gambar 2. Produk sirup jamu yang dihasilkan.

Pada program IPTEKS bagi masyarakat ini, telah dapat dibentuk kelembagaan POSDAYA SRIKANDI dari unit usaha pembuatan sirup kulit manggis dan sirup sereh-secang di desa Kebon Agung, Kecamatan Sukodono, Kabupaten Sidoarjo. sebanyak 21 orang anggota POSDAYA SRIKANDI di desa Kebon Agung, Kecamatan Sukodono, Kabupaten Sidoarjo telah dilatih menjadi personil yang mampu dan terampil memproduksi sirup kulit manggis dan sirup sereh-secang. Dari hasil pelatihan ini, telah berhasil diproduksi 200 botol sirup kulit manggis dan 200 botol sirup sereh-secang yang enak rasanya, tanpa pengawet, pewarna dan pemanis buatan yang sehat dan berkhasiat. Dengan demikian, usaha yang dirintis dari pelatihan ini dapat berlanjut dan menghasilkan manfaat bagi warga RT 25 dan RT 59 desa Kebon Agung, Kecamatan Sukodono, Kabupaten Sidoarjo.

\section{SIMPULAN}

Pada kegiatan ini, telah dilakukan pelatihan pembuatan sirup jamu kepada anggota POSDAYA di Desa kebon Agung, Kecamatan Sukodono, Sidoarjo. Melalui kegiatan pemberian materi serta pendampingan pembuatan sirup, para peserta telah berhasil memproduksi sirup kulit manggis dan sereh-secang yang layak edar. Kegiatan ini telah berhasil memberikan pengetahuan bagi POSDAYA tersebut yang dapat dikembangkan menjadi bisnis yang sangat prospektif ke depannya.

\section{UCAPAN TERIMA KASIH}


Kegiatan ini didanai oleh dana hibah IPTEKS bagi Masyarakat (IbM) dari Kementrian Riset, Teknologi, dan Perguruan Tinggi, Indonesia.

\section{DAFTAR PUSTAKA}

Santoso, S.O. 1995. "Khasiat Tumbuhan Obat sebagai Jamu". Widyakarya Nasional Khasiat Makanan Tradisional. Jakarta.

Siesta. 2014. "Menemukan Jamu di Hotel dan Kafe". www.republika.co.id/berita/ koran/leasure/14/12/16/ngny4a5menemukan-jamu-di-kafe-dan-hotel,16 Desember.

Saerang, C. 2009. "Jamu, antara Realitas dan Tantangan Masa Depan”. www.alumni-ipb.or.id , 7 Januari. 